\title{
Dimensions in Hungarian State Companies - in an Historical and International Perspective
}

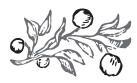

\section{Summary}

The Hungarian economy has been bearing the mark of disadvantage in development due to a late state organisation (at the end of the 10th century) and late rise of the middle classes (second half of the 19th century). The process was made really "vibrant" after the relatively rapid spread of market relations that followed the termination of the feudal production method and social order in the middle of the 19th century, the losses of World Wars I and II and then the nationalisations corresponding to the spirit of the age in Eastern Europe. Between 1947 and the 1980's, state ownership predominated, and then after four decades, the entire system was nearly completely knocked down: this meant the privatisation of collectively owned assets, including radical changes in companies' ownership and management positions. After laying the foundations of the new public finance regime adopted in 2010, the government's regulatory, control and business management achieved its full potential. However, the "time travel" made in this study and overarching more than one and a half centuries also sheds light on the fact that capitalism was built and rebuilt, and to an even greater extent, private ownership was torn down with the state's active participation, and moreover, with its inevitable intervention, which is another unique feature of Central and Eastern Europe, and more specifically Hungary. This study discusses the successive relays (periods) in the mentioned one and a half centuries, with special focus on the procedures that took place in direct state (proprietary) and indirect regulation, in order to provide a scholarly background to the state's current involvement, particularly the prioritisation of companies in community ownership. Consequently, this

Dr Csaba Lentner, Professor, National Public Service University, Deputy Chairman of the Pallas Athéné Domus Meriti Foundation (dr.lentnercsaba@gmail.com). 
lends relevance to outlining the 19th-century building of capitalism, market socialism and the 21st-century proactive, state-managed economic policy in Hungary, ${ }^{1}$ and especially to discussing the logic of the operation of companies that can be considered as the fundamental aggregates of production and to tackle the economic policy governing corporate management.

Journal of Economic Literature (JEL) codes: B5, D00, E00, F15, G01, H6, N00, P2 Keywords: economic management, corporate management, Austro-Hungarian Monarchy, socialist planned economy, market socialism, neoliberal transition to a market economy, proactive state model, Hungary, European Union

\section{INTRODUCTION}

The economic involvement of the state was a basic prerequisite of launching the development of capitalisation in the Eastern and Central European region. ${ }^{2}$ In agreement with the spirit of the time, in the first half of the 19th century, Friedrich List was of the opinion that the German economic area should close the gap by improvement in transportation and support to the industry, with the state acting as a patron, similarly to the developments of Hungarian capitalism after 1867, which was implemented with the state's effective involvement. The neoclassical economists of the second half of the 19th century raised the necessity of state intervention and its method (anew), although its justification and depth remain matters of debate to date. In the position taken by Hanke (1987) and Storr (2001), in a purely private economy deprived of the state, national and community considerations are impaired. On the other hand, excessive government ownership has numerous risks (primarily due to the insufficient enforcement of efficiency and of the ownership approach on a systemic level, which may result in abandoning development projects and allowing the use of obsolete technologies (Megginson and Netter, 2003; Savas, 1987), as we could experience in the planned economy regime. Megginson (2005) is of the opinion that if strategically significant companies have an irresponsible management, the inevitable demand for (repeated) rescues becomes constant. A series of Hungarian and international examples evidence that neither the excessive withdrawal of the state nor the state's excessive sprawl on the economic participants is appropriate. However, there are situations like the one that evolved in the years after the outbreak of the global economic crisis, or gap-closing trajectories, when the means available for economy orientation are indispensable. Based on these, the elaboration of an optimum economy administration and ownership structure is a complex task.

If the Hungarian economic policy, including asset management policy, followed in the past one hundred and fifty years is depicted as being in constant gap-closing due to its considerable lag, the massive economic influence by the state is justifiable, and can entail the expansion of the national wealth (by purchase) and support to compa- 
nies by the means available in the state budget. In other words, with the exception of the soviet type planned economy, the government's intention to influence the Hungarian economy, which was lagging in development or in the state of a crisis, during the past one and a half centuries, was not improper.

A FEW GONSIDERATIONS RELATING TO THE AgE OF THE Austro-Hungarian MONARCHY WITH REgARD TO THE History OF THEORIES ABOUT THE STATE'S POLICY ON ASSETS AND CORPORATIONS

Transition from a society of a feudal hierarchy ${ }^{3}$ to a constitutional monarchy and from the feudal production to a market economy started in Hungary with the adoption of the April 1848 statutes, ${ }^{4}$ and then after the compromise made with the Habsburg Empire in $1867,{ }^{5}$ it strengthened and resulted in the launching of the capitalist method of production for the most part built on industrial companies. The state helped the start and further operation of companies established on the territory of the Kingdom of Hungary by placing orders from them, providing a favourable economic policy regulatory environment and a statutory background to ensure this background. The most outstanding example of state involvement was the state's support of railway construction, but additional forms of support to the industry, subsidies and government purchases also played an important part. A common customs border was established for the entire territory of the Monarchy, ${ }^{6}$ and this ensured protection of the domestic market for all who lived in this dualistic state formation, including protection for Hungarian food industrial products. The government of the time acted as a go-between to encourage the inflow of foreign direct investment. In more specific terms, the state had plants and factories of its own in iron- and steel-making, machine manufacture, silk manufacturing, metals mining, salt mining and the tobacco industry, employing in excess of 50,000 people on the aggregate already in 1900, or 18 per cent of the total number of industrial workers at the time. ${ }^{7}$ Raw iron and steel-making had the highest significance, as the products were used mainly in railway construction and the manufacture of agricultural machines. The Hungarian state took over 10 blast furnaces and 18 refinery sites from the Austrian state treasury. ${ }^{8}$ The state also had shares in private companies, primarily in those that had run into bankruptcy or needed to be saved (e.g. the Testory Metal and Lamp Factory). The Finance Minister was in charge of the management of state-owned assets, which was administered through the Directorate of State Goods. After World War II, Marxist history writing strongly criticised the dualistic state formation, and especially the "factories owned by the treasury" as a corporate form. Lajos Leopold called the capitalist production method implemented on the territory of the Kingdom of Hungary "false capitalism" or "simulated capitalism” (Leopold, 1917, pp. 97, 131). Based on Marx’s propositions, Endre Nagy considered the social character antagonistic to the private capitalist form, and as such, he thought that it represented termination of the capitalist method of production within the limits of the capitalist mode of production (Nagy, 1977). Capital, which is based 
on the social method of production, requires the concentration of the instruments of production and of workforce, and in this case it is directly manifest as social capital, in contrast to private capital, and its companies are all social companies, in contrast to private businesses. As a result, within the capitalist mode of production, a state-owned company also eliminated private capital, similarly to a joint stock company; however, their points of departure are different: the latter is based on a private capital formation, while the transformation of a treasury company is essentially a breakdown of the feudalist mode of production. In respect of the development of the individual companies, Marxist authors did not make a clear distinction between treasury ownership and social nature, and rather they presumed a contradictory coexistence between the various momentums of the treasury and the social nature. ${ }^{9}$ In addition, following the logic of Engels's theory of feudal nationalisation, Endre Nagy, who was one of the main representatives of Hungarian Marxist historiography considered state-owned factories as means to salvaging the power of the agricultural and feudal social layer to the next social order.

In contrast to Marxist historiography, it can be established that the political consolidation had a beneficial impact on the development of Hungary. The situation that followed the liberation of serfs ${ }^{10}$ acted as an economy boosting factor for the political and economic élites alike, and made the creation of the conditions for capitalist development inevitable. ${ }^{11}$ "The basic principle of the official economic policy remained liberalism all the time. However, the situation of the national economy and the difficulties of development necessarily required the increasingly direct intervention of the state. This was also admitted by the advocates of liberal economic policy (Katus, 2009, p. 151). Moreover, László Katus also ascertains that "right after the Compromise, the state undertook a direct role in building a modern infrastructure. Private railway companies were supported by state interest guarantees and shipping companies by annual subsidiaries" (Katus, 2009, p. 152). Government bonds were issued for the establishment of railways and sewers (1867, Art. 13). Act 44 of 1881 on the tax benefits granted to the Hungarian industry provided government allowances to the factories "equipped in accordance with the current technical development" if they "manufacture goods that have not been made in Hungary so far" and any other factory existing or to be established if they manufacture industrial products listed in the act. In 1872, guilds were abolished by law in Hungary, thus paving the way for the establishment of modern business organisations. After 1875, in accordance with the German example a statutory regulation allowed the establishment of general partnerships, limited partnerships and joint stock companies. ${ }^{12}$ These state actions had a key role in the commencement of capitalist development in Hungary, but due to the late start and undercapitalisation, all this was possible in the form of a governmentcontrolled capitalism, in a system including the state as the establisher of corporations, while also supporting $\mathrm{p}$ private companies and placing orders to them. In this respect there was no significant shift between the two World Wars, and in addition, state involvement increased, especially through government purchases from private companies, among others, as a result of the Györ armament programme.${ }^{13}$ In order to 
provide a proper grounding for the assessment of the economic history, a brief mention should be made of the fact that the Kingdom of Hungary entered the war on the side of the central powers, and being a defeated party, after the 1920 Peace Dictate, it lost two-thirds of its territory, population and other economic resources. Its territories were annexed to the neighbouring countries and newly established countries that had fought on the side of the Entente, what is more, even the Austrian part of the former Austro-Hungarian Monarchy was given Hungarian land. This unfair peace treaty, in effect to this very date, urged the political leadership and moreover, every social layer, between the two World Wars to take revenge, and the economic administration was subordinated to this intent. ${ }^{14}$ In World War II, Hungary was defeated once again, all the results of the consolidation between the two World Wars were lost, the country lay in ruins, and as from the spring of 1945, it came under uninterrupted soviet communist influence backed by the permanent presence of the soviet occupying forces up unto the change of regime. ${ }^{15}$

\section{Asset Management Poligy in the Planned Egonomy - The Soft Budgetary Limit}

Between 1945 and 1949 the entire privately owned Hungarian industry, including companies, mines and banks, were nationalised, and the established collective property served the purposes of the planned economy according to the guidelines, and what is more, requirements of the "plan-statutes". As Tamás Sárközy discussed it, the 1959 Civil Code codified a system with state holding considered as the primary property or public holding, while the secondary social property was the collective (kolkhoz) type co-operative property (Sárközy, 1991, pp. 11-12). In addition, the state holding was internally uniform and undivided, and the state-owned corporations set up as sub-holdings created in the so-called institutional type of property, only managed and "operationally" administered the state assets under the leadership of a director appointed from above. In this structure, the private ownership of the means of production were extremely limited; "capitalist" private ownership of an entrepreneurial type was prohibited, and consumer goods, which were extremely scarce due to the low standard of living, constituted personal property, acknowledged as a socialist form of ownership in addition to social (state and cooperative) property.

In the planned economy system, the national economic plans set the expected performances in a breakdown of companies, and assigned all the input the companies were allowed and obliged to manage, from human resources through raw materials and bank loans to state subsidies. The operation of socialist companies was permeated by a voluntarist approach, especially in the first decade of building socialism, when little attention was paid to initiatives and financial interests whether on the level of corporations or of employees. However, the new economic policy approach that appeared in 1955-1956, ${ }^{16}$ and especially the New Economic Mechanism announced in 1967 and started on 1 January 1968, brought forward-looking changes in the management of state companies. The new direction, called "methodical market regulation" 
mitigated regulatory limitations and enforced price and cost relations in an increased extent. Moreover, it paid higher attention to corporate and employee incentives. In Hungary an experiment started with the increased enforcement of market elements, especially in the management of large companies. Nevertheless, due to efforts at restoration, especially waves of pressure by the Soviet Communist Party and the Hungarian retrograde forces, market socialism failed to take place in Hungary, as the predominance of the planned economy and of state ownership prevented the evolution of genuine market conditions.

However, the peculiar Hungarian company management practice, which had remained in fragments up to the change of regime, differed from that of any other COMECON member. Separately accounted units and business partnerships were allowed to be established within state companies, and the opportunity was given to take out certain units of state companies on rent (this was called "gebin" in Hungarian), especially in catering and the service sector. All these generated a more efficient management of companies' assets and a more intense interest and increase in incomes by the employee-lessees. Despite halt and moderation after the successful initial years, the Hungarian market socialism became a model, and nevertheless improved the performance of the national economy through improvement in the efficiency of state asset management. Hungarian companies became more cost-sensitive, responded more to solvent demand on the market, despite numerous opposing forces of paternalist system elements cut back its speed and prevented its fulfilment, e.g. the "Bucharest price principle" 17 , or the economic management under party control, and most importantly, the unnatural maintenance of the planning system, the economic basis of socialism. The very first heavy blow on planned economy and on the regulated conditions was a steep rise in the prices of hydrocarbon products (and especially mineral oil) at the beginning of the 1970's, which made loss-making in the operation of the highly energy-consuming Hungarian industrial companies irreversible, as they were unable to shift the additional expenditures incurred as a result of rising raw material prices to the market. Thus loss-making business management became systemic, bridging losses became characteristic of the system, and - through exchange rate losses and debt services that could no longer be earned by operation - borrowing from abroad to maintain the paternalism of the socialist state caused the collapse of the system by the end of the 1980's. Naturally, at the final point, the system-specific features of the regime included the impossibility of state company operation and the serial application of the soft budgetary limit, as defined by János Kornai, as a means of (temporarily) fending off such an untenable operation (Kornai, 2014, p. 383, reference on pp. 15-17). Considering its impacts, Kornai considered the syndromes of the soft budgetary limit as an unhealthy phenomenon, as they predispose companies to engage in frivolous spending, in other words, they do not need to be afraid of gross financial problems, because the rescue will provide for their survival despite overspending and loss-making. Secondly, the soft budgetary limit syndrome reduces decision-makers' price and cost sensitivity, because a company that can be confident of being rescued will certainly pay less attention to cost management. Thirdly, still quoting János Kor- 
nai, the soft budgetary limit syndrome rearranges the perceived perspectives and the focus of attention and activity for the organisations demanding rescue or support. This means that less attention is paid to the improvement of the original purpose of the given organisation, and more attention is paid to building good relations with any potential rescuer, and both separately and in the aggregate, these effects deteriorate the efficiency of operation. Moreover, Kornai notes that the soft budgetary limit syndrome has a disruptive impact on social morals, as non-paying debtors are saved, and so the other companies will not make great efforts at fulfilling their obligations and at improving the conditions of reasonable and economical business management either. Kornai analysed the soft budgetary limit syndrome mainly in corporations, while this study exposes its macro-economic connotations.

In addition to the pampering effects of the soft budgetary limit applied to the companies of the planned economy (actually meaning regular rescues), beyond János Kornai's opinion, ${ }^{18}$ it is equally important to highlight the responsibility of the state, i.e. economic management. Situations causing the mass bankruptcy of companies result from the state's economic policy, and thus the loss-making corporate behaviour is mainly a consequence and a manifestation of the incorrect state management on a micro-economic level, and if it becomes general, it may make macro-economic operation impossible, as had happened and essentially caused the collapse of the planned economy by the end of the 1980's, including the bankruptcy of several hundreds of state companies. This is to say that the administration of the socialist planned economy spread the application of the soft budgetary limit to the entire corporate sector, thus disintegrating its own responsibility towards these companies, and this resulted in the bankruptcy of the majority of companies due to "non-optimum" and "imprudent" state-controlled economic management. The economic conditions of transition to a market economy also suffered from the phenomenon called soft budgetary limit. Masses of companies and banks that had been taken into private ownership, and moreover, due to irresponsible foreign exchange lending and lenient state supervision, also local governments and households became insolvent and were rescued from the state budget, which had been strengthened in the meantime. Thus the rescue of the individual units in the sub-system of corporations and even public finances (e.g. community local governments ${ }^{19}$ ) did not exclusively (fundamentally) relate to the previous incorrect business management of those rescued, but also to the insufficiently circumspect management, regulation and control performed by the central government authorities managing, regulating and controlling them. Obviously, the companies and local governments indulging in overspending and disregarding cost management were responsible, but corporate and institutional organisations are embedded in a national economy, and as such, they are in a subordinated position and follow rules. If their management by the state is insufficiently prudent, the regulatory system hinders optimum business management, and the methodology of state control and the powers granted to the controlling authority are insufficient, the unit waiting for a rescue should not be solely blamed for its bankruptcy and sinking into a state that requires rescue. Ultimately, when a state rescues its bankrupt company or, among 
market economic conditions, privately owned corporate or banking entities operating in public administration, in fact, it rescues itself, as the operation of corporate organisations provides the basis of the state. In other words, the rescuer consolidates the consequences of the unfavourable economic climate and environment created by the state itself. János Kornai recommended dispensing with the practice called soft budgetary limit, but actually this would only indirectly trigger the bankruptcy of companies, as ultimately the broader managing and regulatory environment of the companies would go bankrupt, whether in a planned or in a market economy. There was hardly any deterrent or disincentive for companies heading towards bankruptcy, as the environment of their operation was shaped by the state, especially in the Soviet and post-Soviet region.

After the rescue, when, in an optimum case, the bankruptcy of the rescued company is resolved, the state management and control and, not in the least, the corporate management are responsible for enforcing the accounting principle of going concern, for creating the conditions of sustainable management and for carrying on operation accordingly (Lentner, 2013; Zéman and Lentner, 2018).

If the companies operating in the planned economy and the initial (market-oriented) enterprises organised around them (separately accounted units, economic partnerships and leased corporate units) were allowed to achieve their full purpose, they could have provided a sound base for the decomposition of the socialist planned economy without a major crisis. The New Economic Mechanism, which focussed on endogenous factors, could have spilled over to a social market economy with companies retaining their original forms, perhaps broken down to clearly delimited units, which could have been given into employee ownership. Instead, the state budget, which had been gradually running short of resources, corporate managements incapable of innovation, the employees, who had grown inert in the course of several decades, limitation of the efforts made at the full enforcement of financial interests, and most importantly, the absence of capital gradually changed the direction of the economy and shifted it to foreign direct investment and the resettlement of foreign companies in Hungary.

ASSET POLICY AND CORPORATE CONDITIONS

DURING THE TRANSITION TO A MARKET EGONOMY

(BETWEEN THE 1980 'S AND 2010$)^{20}$

According to the research by Éva Voszka, already the analyses of Western Europe in the 1980's called the attention to the fact that in large private companies, where ownership is separate from management, control and incentives encounter the same problems at public property does, and therefore in the case of companies facing privatisation efficiency improvement may fall below the expectations (Voszka, 2018, p. 141). In other words, Voszka thinks that the interconnectedness of politics and the economy is not exclusively characteristic of state-owned companies: private companies may also influence central decision, while state purchases and subsidies create 
heavy dependence. Even after 30 to 40 years this assumption remains applicable, especially evidenced by the recent bribery scandals performed in order to win certain public procurement tenders by private companies, but also by demanding the refund of state subsidies granted in return for support to political campaigns, and by obtaining state purchases through means that suggest abuse. Due to the general nature of the system and of human behaviour, the management, control and ultimately efficiency problems encountered in the case of companies operating in the framework of a planned economy remained characteristic during the transition to a market economy, although more moderately than during the period of the planned economy, because private ownership has a more powerful and direct interest than collective ownership. Based on all this, the privatisation of state assets, launched in the late 1980's, and mainly its theoretical grounding should be received with reservations, in other words, giving the majority and the most valuable part of the national wealth into private hands did not solve the problems. However, similarly to the other countries of the post-Soviet region, privatisation in Hungary was built on the axiom that "the state is not a good owner". ${ }^{21}$ The failure of the decades that followed the change of regime sophisticated the general legitimacy of this assumption; however, the companies that continued operation in national ownership also have numerous efficiency-related difficulties.

During transition to a market economy, the state continued to generate budget deficit and government debt, while being incapable of creating incentive conditions for the entire circle of companies in private ownership (including international companies and businesses in Hungarian hands), and moreover, public finances repeatedly ran into increasing operating problems. It can also be evidenced for Hungary that inappropriate economic management and the "general" spread of disinterest at the level of state companies, insufficient motivation - whether of the management or of employees - cut back corporate efficiency. On this basis, the acquisition of corporate property by purchases, whether for resident or non-resident owners, did not contribute significantly to improvement in corporate operation - mainly due to the habits ingrained under the conditions sustained for decades - and a fundamentally new situation was not created. In addition to this base-dependence, the rudimentary market conditions did not encourage competition and generally failed to trigger higher performances in the post-Soviet region. "Without a legal framework of property rights, or commercial institutions such as functioning banks or stock exchanges, without convertible currencies, or even a culture of market exchange, the process of privatisation did not prove an immediate panacea for the structural problems of the economies of these countries as some western advisers enthusiastically promised" (Clarke and Pitelis, 1993, p. 12). As a predominant characteristics also in the Hungarian market economy, through their privatisation or their greenfield investments, well-capitalised foreign companies abounding in know-how created islands of ample innovation, efficiency and profits, however, these isolated circles failed to expand to national parameters, rather they remained secluded and only boosted the total national economy in a limited extent. Although they triggered a favourable propelling 
effect, on minor enterprises operating in their respective regions and respective profiles, mainly in domestic ownership, but this also cemented the dependence of SMEs.

All that said about the circumstances, a sophisticated picture can be given of privatisation in Hungary and the conditions of companies remaining in national (or Hungarian private) ownership. Especially in respect of their efficiency, as it should be noted that the government's economic policy required international companies to pay taxes only far below their tax payment capacities. What is more, in general they were granted resettlement and investment support they could use for further improving their competitive edge, mainly against Hungarian small and medium-sized enterprises. This is to say, a genuine (universal) market economy has never been established in Hungary. In this evolving market space, the most striking example of market competition was seen on the level of public utility companies. The privatisation of public utility companies, which were technically obsolete but organised on a territorial basis and thus had a secure clientele, started as early as the middle of the 1990's. The nature of their services and their geographical dislocation also earned them a monopoly position, and these should have been reflected in the privatisation price paid, but they were sold at a loss. The new owners could expect a secure return on their developments, and this was topped by the government guaranteeing an 8-percent return on assets for them in the privatisation contracts. The amount determined by this method was guaranteed by the state if it was not raised from the payments made by the clients, participating in the transactions as a surety. The enforcement of such a powerful state support prevents the purely market-based assessment of the efficiency and profitability of even foreign-owned public utility companies on the basis of traditional market calculations.

The dependence of transition to a market economy on planned economy as its base, the inherited poor work ethic and the burdensome regulatory environment were especially traceable in the management of state companies, but also affected private businesses. János Kornai calls this process the feed-through of the elements of the socialist system (Kornai, 2012, XV-XVI, XIX, XX-XXVIII). He mentions the effects of values inherited from socialism, bubbles retaining an economy of shortages, and the survival of the soft budgetary limit syndrome. In Kornai's position, wherever state ownership predominates and goods or services are provided to the consumer or user free of charge, the economy of shortages necessarily appears. This applies even more to the market of state healthcare and educational services. After all, in these fields the economy of surpluses, characteristic of capitalism, has not evolved, instead the economy of shortages remained. Calling the quoted proposition into question, we assume that the Central and Eastern European population cannot yet afford to pay the "marketised prices" of the private healthcare and educational sectors. For this reason, the operation of the traditional state-owned service providers is perhaps justified, and provides a higher security of supply for the wider masses than the one a private sector could offer.

However, pushing the complete state sector into the background caused significant tensions at public utility service providers. Households encountered increasing difficulties in paying the ever rising priced set by the public utility service provider 
companies privatised in the 1990's, and a significant amount of debt was accumulated. True, the services provided by service providers improved significantly. During privatisation, the state's assumption was that a private company could operate e.g. a district heating, a water supply or an electricity service provider more efficiently than the state or local governments. Assuming the Hungarian state's permanently tight financial situation, a new and highly capitalised foreign owner was expected to be able to spend more on technical developments. An interesting thing about the companies given ground in the privatisation of Hungarian energy and public utility sectors is that most of them came from continental Europe (Germany and France). Moreover, from countries where the public utility and energy sectors are preponderantly in national ownership. Another interesting thing is that a significant part of the Hungarian public utility companies were purchased by German and French local governmentowned public utility companies. This fact contradicts Péter Mihályi's assumption that the state is a bad owner. Perhaps, in Hungary the state was a bad owner, or rather a frivolous owner, but this is not true everywhere in the world. The genuine remedy the large number of companies and public utilities that went bankrupt during Hungary's transition to a market economy is not the direct application of a soft budgetary limit (repeated rescues), rather, an efficient economic policy securing the sustainable operation of these companies and optimised to Hungarian conditions. But the Hungarian state management was incapable of this.

The decentralisation of other kinds of (classical) public services - for example state and local government administration, and giving the companies performing public services from national ownership into private hands, and thus a shift to profit orientation in these companies according to the underlying philosophy of company management, implemented the DPM paradigm ${ }^{22}$ of the New Public Management, the neoliberal economic theory of the state. For two decades the Hungarian state's economic management operated along these guidelines, in close correlation with the principles of the Washington Consensus, prevailing since the 1970's, and with the Copenhagen Criteria favoured by the European Union, as compliance with the Maastricht Criteria were hoped with their help. Overall, the role of the state was gradually decreased, and within that scope, the economic philosophy of moderating its regulatory and control functions was enforced when the Hungarian State Property Agency and the local governments sold the public utility companies in their ownership, which had been organised on a geographical and supply basis. Subsequently, they only had very slight control and regulatory authority over the internal business management of these companies. After all, due to corporate independence and to the "overemphasised" sanctity of private ownership, after privatisation the state could barely influence and did not have much insight into the procedure of setting consumer prices and the procedure of accounting cost items. In addition, as the privatisation contracts were concluded in an exigency of the seller state, they also provided very little opportunity for any further state or authority control over sales prices as well as further operation. There were hardly any example for such provisions in privatisation contracts, and perhaps even the intent was missing. 
Due to the primacy of profit considerations in the business management of the public utility companies obtained by the new owners, payment tensions increased on the consumer side. Based on all these, one of the key elements among the criteria of state management and state operation, revised in 2010, was the reversal of the decentralisation processes that took place in public finances. In other words, the state centralised the general government (including both the central and the local) budgets. The most important example for this was seen in the field of local governments' debt management, financing and the performance of their duties. Another key action in centralisation was the takeover of private pension funds' assets into government coordination. In addition to centralisation, taking public utility companies into national ownership (through purchases) was another reasonable solution in order to have a say in setting the prices that significantly affect the housing conditions of the population. Once the state became an owner, and also through its reinforced regulatory powers, it could influence service charges. Thus, by enforcement of price regulation, the public utility companies repossessed into national ownership reduced the service charges. Instead of the priority of profit, service of the public good was given a key role in their operation, and especially in their regulatory environment. ${ }^{23}$ The previous DPM paradigm of the obsolete NPM system was thus replaced in state operation by a new Weberian and French étatist state model, the CPNG ${ }^{24}$ philosophy of the state's active economy influencing activity. The duty of the state and its controlling authorities is to constantly supervise the efficiency of the business management triggered by regulation and to monitor the operation of public utility companies. Then the State Audit Office was required to fulfil the majority of the duties related to making comprehensive proposals (Domokos et al., 2016, pp. 178-198).$^{25}$ The absurdity of the previous situation is well illustrated by the fact that up to 2011 the State Audit Office had not been authorised to audit public utility service provider companies in local government ownership. In other cases, due to regulatory deficiencies, the fact-finding audits performed by the State Audit Office were improperly utilised and failed to entail consequences condemning the transgressor and extorting normalisation of the situation.

Returning to the 1990's: in the case of companies given into private hands during privatisation, the paid sales prices have been the matter of debate to date. Undoubtedly, the majority of state companies put up for sale was characterised by an obsolete technical level and narrow market opportunities. The exigency of the seller state was manifest in the resources that were insufficient for the continuation of operation or even for survival, and in the absence of any concept whatsoever in state management. Bianka Parragh highlights that the first "spontaneous privatisation" started already in 1989 without the formulation of a public privatisation strategy. Numerous highly significant questions of the property transfer remained unanswered, there was no act on privatisation, there were no rules for inviting tenders, proposals or quotes, and asset valuation was also unregulated, thus corporate self-governments had a broad opportunity to move assets. ${ }^{26}$ Theoretically, the price of a company put up for sale is determined by its equity and its market prosperity. However, György Matolcsy found that 
impairment was basically unrelated to company privatisation; rather it was caused by the aggregate impacts of high inflation, import liberalisation and the exchange rate policy (Matolcsy, 1991, pp. 227-229). Árpád Kovács and Gusztáv Báger think that such a rapid depreciation of companies would also have taken place without privatisation (Kovács and Báger, 2004, p. 25). Based on all this, it can be concluded that the privatisation of these companies was an involuntary solution among the given suffocating macro-economic conditions, which at least created the opportunity for additional operation by the new owners. Giving these companies into private hands were often characterised by circumstances that raise the suspicion of criminal offences. ${ }^{27}$ After twenty five years, as a result of a proactive state operation, today the circumstances of business management seem to be returning to normal, and the problems encountered during transition have been resolved.

After all, if we seek to know the efficiency of the assets that provided the Hungarian economy's technical base and were "operated" in a corporate framework, or in other words, the total corporate efficiency achieved by privatisation, a depressing picture is obtained. In an analysis by Péter Mihályi (a neoliberal advocate of "unlimited" privatisation), between 1989 and 2009, the average rate of GDP growth (resulting for the most part from corporate performance) was 1.1 per cent (Mihályi, 2010, p. 51). According to Mihályi, this value is dramatically low, but it represents a change in the trend in comparison to the 3.6 per cent characteristic of the period between 1968 and 1989. In the first two decades after the change of regime, while the number of the population dropped by only 3.6 per cent, the number of active wage earners dropped by 15.4 per cent from 5.2 million to 4.4 million. It should be added and should not be forgotten that at the beginning of the change of regime, when corporate management was changed to a new mode (forced by deteriorating economic conditions and as a result of privatisation), 1.5 million industrial and agricultural jobs had been terminated up to 1995 and an intention to reintegrate this huge mass of unemployed into the labour market was only shown after 2010, when the opportunity was created by a proactive (once again) state-managed economic policy. ${ }^{28}$

György Matolcsy related the privatisation procedure to the debt portfolio that put a heavy pressure on the country and to the resulting compulsion. "Despite the fact that we were given help for a spill-over and launched the sale of state assets, primarily to foreign investors, we did not escape the debt trap. From approximately USD 21 billion in 1990, by the end of 1995 the gross debt to the rest of the world had increased to about USD 32 billion” (Matolcsy, 1998, p. 25). It follows from Matolcsy's argumentation that the re-organised technical base that had been given, for the most part, to private hands, mainly to foreigners, was incapable of releasing Hungary - with the help of the state's economic management - from the grave debt crisis that had evolved by the end of the 1980's, and moreover, as privatisation gradually spread, the crisis deepened. Indirectly, this gives a depressing picture of the performance of market economy (mostly already in private ownership). This means that Péter Mihályi's "inherent" concept that the state is a bad owner can be received with even higher reservations. Naturally, the state may not be the best owner, but it is, or was in the 
past, far worse in leadership and economy management, i.e. it has a limited capacity to create an optimum economic policy for companies. In a historical retrospect, this was the case both in the period of the planned economy and in the decades of transition to a market economy. Companies are basically not to be blamed for corporate failures, whether made in the period of the planned economy or during transition to a market economy, as they were caused by incorrect economic policies, which put the companies owned by the state or sold to private owners into chronic loss-making. The state mitigates its unsolid economy influencing, regulatory and controlling role by rescuing (through the soft budgetary limit facility) corporations, from time to time, as illustrated by numerous examples since the restart of proactive state operation (after the 2010 change of government and economic philosophy), to resolve the problems that had been accumulated in the previous decade. After all, in summary, the raw, neoliberal Hungarian market economy practice that followed the planned economy can be represented in a single sentence or the title of one of my previous studies: Is the Hungarian market economy a genuinely higher-level economic model than the planned economy system modified by market elements? (Lentner, 2010, pp. 11-13). I could not give an affirmative response to this question in my analysis presented at a plenary session at the Pázmány Péter Catholic University in 2010.

\section{A ROAD TO THE PRESENT - OR A SUMMARY 29}

In relation to the "completion" of transition to a market economy and the regulation of a new, proactive state operation practice, Tamás Sárközy thinks that when redefining ownership conditions, the government has directly taken (naturally, based on authorisation by the electorate) the right of economic constitutionality (Sárközy, 2014, pp. 285-286). Professor Sárközy argues that economic constitutionality includes the direct or indirect determination of a country's economic system. In 1989-1990, following the German example, Hungary's economic system was defined as a social market economy in the Hungarian constitution. However, this definition was left out of the Fundamental Law that set the framework (among others) to the post-2010 proactive economic policy practice, in other words, the economic system is not defined, and moreover, the discussion of the system of ownership is also very low-key. It does not discuss the ratio of public assets to private assets, and ultimately (indirectly) this provides a general public authorisation for the government to control and determine the desired processes. Moreover, to continue along Sárközy's train of thoughts, our economic system should be a market economy based on specifically Hungarian features but also compliant with the basic economic and political principles recorded in the Treaty of Rome establishing the European Union. In other words it is based on private ownership, i.e. it is built on the market competition of autonomous market participants. Consequently, it is self-regulating but - in order to mitigate the past discrepancies - it is complete with state regulation that is stronger than in the past decades. This ensured fair procedure, good faith, equitableness and co-operation between the various economic participants, and integrates the social element, including 
the corporate social responsibility of large corporations, in market competition. Our economic system should be based on an ownership structure based on private property as a fundamental element, completed by public property (owned by the state, local government or public body). However, the fulfilment of these requirements rules out the kind of state capitalism as applied in most successor states of the Soviet Union, but it is in agreement with the obligations undertaken vis-a-vis the European Union in the relevant international treaties. ${ }^{30}$

Simultaneously with this abstract legal definition, it should be emphasised that the Article 38 of the new Fundamental Law clearly points out that the requirements of retaining and protecting the national wealth and of the responsible management of national assets are specified in a cardinal law. The Fundamental Law also provides that a cardinal law should specify the scope of the state's exclusive ownership and exclusive economic activity, as well as the limits to and conditions of the alienation of national assets given priority for considerations related to the national economy. The purpose of act on national assets (Act CXCVI of 2011) is, in agreement with the Fundamental Law, to define, on the highest level of legislation, the general principles of protecting national assets constituting the primary infrastructure for the performance of public duties by the state and by local governments, and of managing these assets. The purpose of the Fundamental Law and the act about national assets is to enforce the principle of division of public duties performed by the state and by local governments when assets are allocated for the performance of a given duty from central ownership to local government ownership, or if the particular duty is assigned to the state, from local government ownership to state ownership. The act stipulates that the primary purpose of national assets is the performance of public duties, and defines the concept of "public duty" in general terms, with due consideration to the meaning of the terms "public duties" and "public services" given in other statutory regulations. Thus the act on national assets was drafted with the aim to enforce the goods declared by the Fundamental Law to constitute the ownership of the state and of local governments as national assets. The cardinal act, on the other hand, defines the use of national assets in public interest and for the purpose of public needs, and requires the retention of national values in order to secure coverage for the needs of future generations. In order to fulfil all these goals, the transparent and responsible management of national assets are specified as requirements. It follows from these statutory definitions that the public utility companies given into state and local government ownership must serve the public good instead of seeking profit. The State Audit Office's audits, proprietary control, inspections by the authorities and the committed work of the corporate management are meant to serve the efficiency of their corporate management. In addition to disciplined budgetary (financial) procedures, the state makes efforts at achieving its objectives set in the Fundamental Law more directly and operatively.

Therefore it is essential that 2011 was a watershed in the management of national assets. While the previously effective Act CVI of 2007 provided that state holdings had already been pulled down during the previous two decades, institutional and mass 
privatisation had been closed. Thus the conditions had been created for making a coherent statutory regulation of the remaining state property, which was "still very significant" in 2007. As "it is disproportionate to public duties," the purpose is to "reduce the currently excessive amount of state-owned assets". In other words, the previous political leadership thought that assets should only remain in state ownership over the long term if it is justified by retention of the value of the asset, the nature of the asset or an overriding economic policy interest or consideration.

A comparison of the 2007 and 2011 acts on national assets reveals an essential difference: the 2011 statutory regulation sets the goal of increasing national assets, and thus to perform the widest possible scope of public services in the interest of the public good, with the "implementing" organisational units set up for the satisfaction of public needs at the highest possible standard. The new approach expands the scope of public duties and intends to improve its quality, by expansion of the circle of companies in national ownership and improvement of their efficiency.

\section{SUMMARY}

To a great extent, a particular country's asset management and corporate policy are determined by its development trajectory, geopolitical location and dimension, and its history. The state cannot create an efficient asset management (including the state's involvement as an owner and the strength of its regulation in respect of the companies) on the assumption of dependence on a base; it is only possible with consideration to the capacities, realistic endowments and demands of the society and the economic participants. This is evidenced by the events of Hungarian asset management policy in the past one and a half centuries.

The mass privatisation launched in the 1980 's was similarly harmful, primarily because it caused financial and social damages, similarly to the forcible nationalisation performed after 1945 with reference to economic reason. Both distorted the conduct of businesses: the nationalised companies and their employees interests were reduced, while companies during the transition to a market economy, with the exception of a few international corporations, were never brought into a competitive position. Moreover, a large number of the former state companies went bankrupt as a result of the incorrect approach to the economic policy role of the state. The market economy environment re-shaped since 2010 is characterised by state control, similarly to the period of the Austro-Hungarian Monarchy, when the state assisted in the "preparation" of companies for market competition and for coping with the market requirements. The goal, just as in the period of the Monarchy, is the diversity of company sizes, and the state provides a supportive economic policy environment for the achievement of this goal.

Catching up is, mutatis mutandis, always a matter of closing the gap to a more developed entity. But an analysis of contemporary England and its lessons provide an appropriate benchmark for the arguments in favour of the necessity of state influence on the economy in Hungary. In The Wealth of Nations, Adam Smith argues in favour 
of an "invisible hand", or the invisible state, in a period when England had already become the most developed state of the world. However in one of his earlier works (entitled Inquiry into the Nature and Causes of the Wealth of Nations), he determined the tasks of the state, and of the ruler who managed the state, in a positive sense. These include the protection of society, the obligation to operate the administration of justice and running public utilities and public institutions. In order to be able to meet these expectations, the state needs to be strong. These are the developments currently in progress in the post-Soviet region, especially in Hungary In other words, the state must create the framework conditions of asset management policy and corporate operation, and when required, it must reconsider and restart the procedure, just as after the feudal mode of production or in the period that followed the world economic crisis after the millennium entailing a budget weakening.

\section{Notes}

1 It is important to note that due to constraints on length, this sketch only provides limited academic information, however, the book entitled: A magyar állampénzügyek fejlôdéstörténete a dualizmus korától napjainkig. Nyugattól keletre, Kelettól nyugatra [The evolution of public finances in Hungary from 1867 to our day. East from West, West from Asia] (L'Harmattan Publishers), published early in the summer of 2019 offers ample data. This work is available in English (under the title East of Europe, West of Asia) since the beginning of 2020 and in Chinese and French since the spring of 2020. The apposite subtitle East of Europe, West of Asia refers to the unfortunate "inbetween" character of the Hungarian economic policy, interposed in the middle of Europe, not merely in a geographical sense of the word.

2 Catching up, mutatis mutandis, is always a matter of closing the gap to a more developed entity.

3 The Kingdom of Hungary, torn into three as a result of the Ottoman Empire's conquest, was under the constant pressure of uninterrupted wars, and then from the 17th century, after the Turks had been thrown back, subjugation to the Habsburg Empire had an unfavourable impact on the country's economic development. The fact that the Habsburg Empire, including the Kingdom of Hungary, was left out of the world's new economic trends (e. g. from the economic expansion resulting from the discovery of America) considerably limited its positions and economic standard, and the empire gradually degraded into a medium power. Its social conditions were characterised by a late rise of the middle classes and by inherited serfs, an institution that evolved everywhere east of the River Elbe in the 16th and 17th century, and achieved its full purpose in Hungary in the 18th century. Its evolution was closely related to the reduction, termination or absence of institutions and relations based on goods, which considerably slowed economic growth in the Eastern and Central European region, as the conservation of the feudal conditions prevented the financial fulfilment of the most important element of the economy: man, while the other important factor of production, namely, land was not negotiable (it could not be sold or mortgaged). Inherited serfdom essentially means that serfs were inherited like goods and were not allowed to move from the land they toiled (they were "earthbound"), in other words, the ownership rights of the serf and the land belonged to the landlord and his successors. This also included serfs not obtained by the landlord but inherited from his forefathers. The use of this term spread for the most part on the basis of F. Engels's works.

4 At the beginning of the 19th century, the idea of economic and political independence came to the foreground. This period is called the Age of Reforms, however, in the wake of the largest European capitals, by the spring of 1848 this had evolved into a revolution and then an armed war of independence, which was bloodily put down at the end of the summer of 1849 by the army of the Russian Empire, which hastened to the assistance of the Austrian emperor and heavily outnumbered the Hungarian rebels. The statutes adopted in April 1848 (voted for by the very last National Assembly of the nobility), terminated 


\section{Civic Review · Vol. 15, Special Issue, 2019}

the nobility's tax exemption and the taxes and duties payable and services provided to landlords by serfs free of charge, and eliminated serfdom.

5 Initially, the two decades that followed the 1848-1849 War od Independence up to 1867 only saw retaliations by the Austrians and passive resistance by the Hungarian nation. Following the Austrian example, a "Prussian" kind of tax administration was adopted, which created the basis of public finances. Although at that time the nation contemplated it belligerently (refusal to pay taxes was high), subsequently it benefitted from the system. The Habsburg Empire, which repeatedly lost wars on various European battlefields and suffered from its shrinking political influence, and the Hungarian society, wishing to develop, were driven towards a compromise, which finally took place in 1867 on the basis of mutual interests.

${ }_{6}$ One of the most important element of the economic compromise concluded with the Habsburg Empire (or the "Austrian Emperor") in 1867 was the commons customs border, which protected the producers of the empire, as a kind of a protectionist instrument.

7 Source of data: Berend and Ránki, 1972, p. 79.

8 Source of data: Sándor, 1954, p. 201.

9 Based on Marx, 1909 and Nagy, 1977.

10 Act IX of 1848 abolished services provided to landlords free of charge and the administration of justice by squires and Act XIII of 1848 terminated the obligation of tithing.

11 Mention should be made within this framework of Act XV of 1848, which abolished the ban on selling the inherited estates of noblemen, allowing the sale and mortgaging of property, and thus facilitating the movement of capital.

12 Act XXXVII of 1875 on commerce and trade.

13 This was an army development programme with a budget of one billion pengó, with a term of five years set by the Darányi Government.

14 The Peace Treaty of Trianon and its consequences are detailed by historian Béla Makkai (Makkai, 2019).

15 The Yalta Conference declared Hungary to belong to the area within the control of the Soviet Union, similarly to other, surrounding Eastern and Central European countries, before the end of the war.

16 Easing the framework of the bigotric and rules-based soviet type Hungarian planned economy started in 1955. In 1956, first in the soviet-controlled area after World War II, armed combat broke out in Hungary. Although vastly more numerous soviet troops stifled the 1956 Revolution and War of Independence, the same normative soviest economic policy could no longer be enforced in the People's Republic of Hungary. One of the consequences of the implementation of the 1968 reform gained Hungary the reputation of the "most cheerful barrack" in the Easter block. Initially, improvement in the standard of life was financed from a more efficient enforcement of financial interests, and later on, after the (unfortunate) moderation of the former, from foreign loans and borrowing. By the end of the 1980's, the economy of the Hungarian People's Republic, which was "operated" from western loans, went bankrupt economically and politically.

17 The Hungarian industry, which was compelled to import energy, received mineral oil within the framework of COMECON, mainly from the Soviet Union, for a price based on the average world market price of the previous five years. Although this was a discount, primarily after the outbreak of the 1973 world market oil price, this delayed effect pampered the Hungarian economy, made it energy-wasting and deteriorated its efficiency, and consequently it increasingly slipped back in the world market competition. As a simultaneous problem, as a result of curbing financial interests from the 1970's employee motivation, discipline and performance dropped. As the institution of socialism, and simultaneously, both employee and corporate interests were cut back, so the Hungarian economy's dependence on external loans increased. Instead of more efficient production, the standard of living was improved by increasingly intensive borrowing.

18 Appreciating the school-forming work of János Kornai, the best known Hungarian economist, mention should be made of the fact that Kornai considered the application the soft budgetary limit and feedthrough of this phenomenon as a flaw not only of socialism but also of the two decades of transition to a market economy, and especially of the proactive state model applied after 2010 . These problems are also 


\section{Csaba Lentner: Dimensions in Hungarian State Companies - in an Historical...}

tackled below, however, it is important to point out right here that the flawed economic policy, which did not match either the endowments and requirements of the productive resources or the production and social conditions, were "created" from top to bottom, and moreover, imported (whether from the soviet planned economy or from the Anglo-Saxon neoliberalism), including the economic practice ("only") forced on companies (and did not evolve at that level), was the principal cause of mass losses. Thus arising from the peculiar features of the system, it was the elimination of the "optimum" market during the socialist planned economic system and the application of coarse market rules during transition to a market economy that triggered the bankruptcy of masses of companies and banks. In these cases the rescue of companies and banks (after all this) was a "moral obligation", as the state made efforts at preventing the wide spread of bankruptcies and society's sinking into anarchy.

19 For more details about the state consolidation of Hungarian local governments that went bankrupt in the framework of a neoliberal market economy operation (and the application of the soft budgetary limit), see Lentner, 2014.

20 Transition from the socialist planned economy into a rude market economy started as early as the end of the 1980's, during the planned economy "managed" by the Hungarian Socialist Party. However, this was a forced procedure. The participants of the system were helpless and had no concept, but they endeavoured to save their power, and so they allowed spontaneous privatisation, in other words, the acquisition of assets and property by those affiliated to the system. Moreover, at state companies the management discipline completely eroded. In such an economic policy practice of "turning the bull loose", abuses were made in masses. The commencement of the market economy was not an ethical procedure at all. Simultaneously, sanctions were mitigated and moreover, due to the absence of preparedness by the law enforcement agencies, most of the mismatches and anomalies became blurred and faded away. The political changes that resulted in a multi-party system were brought about by the 1990 general elections, however, the situation did not improve, at least initially, with the adoption of a raw and "rootless" neoliberal market economy in Hungary. With the change of regime, the "good" part of the old system (government planning, coordination and control) were also discarded, but an efficient new system (including the quick decomposition of state ownership and the moderation of regulation and control) was not set up.

21 In the publications by Péter Mihályi, this is a repeated assumption about the start of the change of regime. See, for example: Mihályi, 2010 (quote from page 5).

22 Decentralization, Privatization, Management.

23 In fact, the "mandatory reductions in utility bills" started during the "period" when most of the public utility service providers were in private hands. For further details of this process, see Lentner, 2015.

24 Centralization, Nationalization and Public Good. For further details see a CNPG model, see Lentner, 2017.

25 The authors give account of the operation of public utility companies, which is, for the most part, not cost efficient and does not comply with the relevant statutes, including the Accounting Act. The factfinding activity performed by SAO, and according to the report of the auditors, the restoration of compliance and the continuation of operation with the approach expected of a careful owner may release additional reserves at public utility companies and may lay the basis of further reductions in prices and charges.

26 Based on Bianka Parragh's position, the act on business organisations, which entered into force in 1989 and the act on transformation, also effective sing 1989 (Act XIII of 1989) gave corporate self-governments ample room for manoeuvre. See Parragh, 2014.

27 Mihály Tóth, a specialist of this topic, thinks that a small fraction of the criminal offences can be related to the privatisation performed at the time (Tóth, 1995). This is due to the fact that the law enforcement agencies were unprepared and the cases were complex, and these made the recognition of non-compliance more difficult.

28 Based on the competitiveness research conducted by Attila Chikán and his colleagues (Chikán et al., 2019), gave a dismal view of the period between 1995 and 2018.

29 For more details on the operation of the post-2010 proactive state model in the economic space, see the works of György Matolcsy, László Domokos and Árpád Kovács. 


\section{Civic Review · Vol. 15, Special Issue, 2019}

30 At the same time, in relation to the "regularities" and sustainability of the "illiberal" economic policy practice, László Csaba expresses his doubts (Csaba, 2019), while Péter Mihályi and Iván Szelényi assign low value to the role of the layer of businessmen, dependent on economic policy (EU funds) and on actual politics, in the effective productive sectors and think that over the longer term they will be pushed to the background (Mihályi and Szelényi, 2019). It is, however, a fact that Hungary's economic positions improved considerably after the 2010 change of government.

\section{REFERENCES}

Berend, T. I. and Ránki, Gy. (1972): A magyar gazdaság száz éve [A hundred years in the Hungarian economy]. Kossuth Könyvkiadó, Budapest.

Chikán, A. et al. (2019): Versenyben a világgal? A mikrogazdasági versenyképességi kutatások eredményei, 1995-2018 [Competing the world? Findings of the micro-economical competitiveness research, 19952018]. Vezetéstudomány, Vol. 50, No. 12, pp. 16-31, https://doi.org/10.14267/veztud.2019.12.03.

Clarke, T. and Pitelis, C. (1993): Introduction. In: Clarke, T. and Pitelis, C. (eds.): The Political Economy of Privatization. Routledge, London.

Csaba, L. (2019): Unorthodoxy in Hungary: an Illiberal Success Story? Post-Communist Economies, No. 31, pp. 2-14, https://doi.org/10.1080/14631377.2019.1641949.

Domokos, L. et al. (2016): Renewal of Public Management. Public Finance Quarterly, Vol. 61, No. 2, pp. $178-198$.

Domokos, L. (2019): Ellenôrzés - a fenntartható jó kormányzás eszköze [Audit - a means of good governance]. Akadémia Kiadó, Budapest.

Hanke, S. H. (1987): Privatization Versus Nationalization. In: Hanke, S. H. (ed.): Prospects for Privatization. Academy of Political Science, New York.

Katus, L. (2009): Az állami ipartámogatási politika háttere a dualizmus korában [Background to the state's policy to support the industry in the period of the Austro-Hungarian Monarchy]. In: Rab, V. (ed.): Válságos idók tegnap és ma. Pénz, gazdaság és politika a 19-21. században [Clear times yesterday and today. Money, the economy and politics between the 19th and the 21st centuries]. Pannónia Könyvek, Pécs, pp. 151-166.

Kornai, J. (2012): A szocialista rendszer [The socialist system]. In: Kornai János válogatott munkái II [Selected works of János Kornai II]. Kalligram, Bratislava.

Kornai, J. (2014): A puha költségvetési korlát [The soft budgetary limit]. In: Kornai János válogatott munkái II [Selected works of János Kornai II]. Kalligram, Bratislava.

Kovács, Á. (2019): A magyar költségvetés „európai” szemmel - diagnózis és anamnézis [The Hungarian budget through the eyes of a "European" - a diagnosis and a case history]. In: Kovács, L. P. (ed.): Közel Európa távol [Nearby Europe far away]. Éghajlat Kiadó, Budapest, pp. 287-322.

Kovács, Á. and Báger, G. (2004): Privatizáció Magyarországon I [Privatisation in Hungary I]. State Audit Office of Hungary, Budapest.

Lentner, Cs. (2010): Valóban magasabb szintú gazdasági modell a magyar piacgazdaság, mint a piaci elemekkel átitatott tervgazdasági rendszer? [Is the Hungarian market economy a genuinely higher-level economic model than the planned economy system modified by market elements?] Heller Farkas Füzetek, Vol. 8, No. 1-2, pp. 10-16.

Lentner, Cs. (2013): Enforcement of the Principle of Going Concern: with Special Regard to Public Service Providers. In: Hyránek, E. and Nagy, L. (eds.): Zborník Vedeckých Statí: Priebežné výsledky riešenia grantovej úlohy VEGA č. 1/0004/13: Aktuálne trendy a metódy vo finančnom riadení podnikov a ich vplyv na finančnú stabilitu podniku. Vydavatelstvo Ekonóm, Bratislava, pp. 9-17.

Lentner, Cs. (2014): The Debt Consolidation of Hungarian Local Governments. Public Finance Quarterly, Vol. 59, No. 3, pp. 310-325.

Lentner, Cs. (2015): A vállalkozás folytatása számviteli alapelvének érvényesülése közüzemi szolgáltatóknál és a költségvetési rend szerint gazdálkodóknál - magyar, európai jogi és eszmetörténeti vonatkozásokkal [The enforcement of the accounting principle of going concern by public utility service providers and 


\section{Csaba Lentner: Dimensions in Hungarian State Companies - in an Historical...}

public sector organisations - with Hungarian and European legal and historical examples]. In: Lentner, Cs. (ed.): Adózási pénzügytan és államháztartási gazdálkodás [Fiscal policy and the management of public finances]. Nemzeti Közszolgálati és Tankönyvkiadó, Budapest, pp. 763-783.

Lentner, Cs. (2017): New Concepts in Public Finance After the 2007-2008 Crisis. Economics \& Working Capital, No. 1-4, pp. 2-8.

Lentner, Cs. (2020): East of Europe, West of Asia. L'Harmattan Publishing, Paris.

Leopold, L. (1917): Elmélet nélkül. Gazdaságpolitikai tanulmányok [Without a theory. Studies in economic policy]. Benkô Gyula Cs. és Kir. Udv. Könyvkereskedése, Budapest.

Makkai, B. (2019): Trianon - "hol nemzet süllyed el..." [Trianon - "Where a nation is lowering"]. Polgári Szemle/Civic Review, Vol. 15, No. 1-3, pp. 344-364, https://doi.org/10.24307/psz.2019.0922.

Marx, K. (1909): The Capital. A Critique of Political Economy. Vol. 3, Ch. H. Kerr and Co., Chicago.

Matolcsy, Gy. (1998): Sokk vagy kevés? [Too much shock (or too little)?] Kairosz Kiadó, Budapest.

Matolcsy, Gy. (1991): Lábadozásunk évei [The years of our recovery]. Privatizációs Kutatóintézet - Tulajdon Alapítvány, Budapest.

Matolcsy, Gy. (2016): Economic Balance and Growth. Kairosz Publishing, Budapest.

Megginson, W. L. (2005): The Financial Economics of Privatization. Oxford University Press, New York, https://doi.org/10.1093/0195150627.001.0001.

Megginson, W. L. and Netter, J. M. (2003): History and Methods of Privatization. In: Parker, D. and Saal, D. (eds.): International Handbook on Privatization. Edward Elgar Publishing, Cheltenham, pp. 25-40, https://doi.org/10.4337/9781781950951.

Mihályi, P. (2010): A magyar privatizáció enciklopédiája I-II [Encyclopedia of privatisation in Hungary]. Pannon Egyetemi Könyvkiadó - MTA Közgazdaságtudományi Intézet, Budapest.

Mihályi, P. and Szelényi, I. (2019): Rent-Seekers, Profits, Wages and Inequality. The Top 20\%. Palgrave Pivot, Springer International Publishing, Cham, https://doi.org/10.1007/978-3-030-03846-5.

Nagy, E. (1977): Állami beavatkozás a monarchiabeli Magyarországon [State intervention in Hungary during the period of the Monarchy]. Gazdaság és Jogtudomány, Vol. 11, No. 1-2, pp. 85-115.

Parragh, B. (2014): A rendszerváltás befejezése: A siker kapujában 25 év után [The completion of the change of regime: At the gate of success after 25 years]. Polgári Szemle, Vol. 10, No. 3-6, pp. 78-94.

Savas, E. S. (1987): Privatization. The Key to Better Government. Chatham House Publishers, New Jersey.

Sándor, V. (1954): Nagyipari fejlódés Magyarországon 1867-1900 [Development of the large industry in Hungary]. Szikra Kiadó, Budapest.

Sárközy, T. (1991): A privatizáció joga Magyarországon. Indulat nélküli elmélkedés tényekról, lehetôségekról [The law of privatisation in Hungary. Reflections on the facts and options without rancour]. UNIÓ Lap- és Könyvkiadó, Budapest.

Sárközy, T. (2014): Kétharmados túlkormányzás [Governing with a two-thirds majority]. Park Kiadó, Budapest.

Smith, A. (1940): Vizsgálódás a nemzetek jólétének természetéról és okairól [An Inquiry into the Nature and Causes of the Wealth of Nations]. Reprint, Magyar Közgazdasági Társaság, Budapest.

Smith, A. (1776): An Inquiry into the Nature and Causes of the Wealth of Nations. http://metalibri.wikidot.com/ title:an-inquiry-into-the-nature-and-causes-of-the-wealth-of.

Storr, S. (2001): Der Staat als Unternehmer. Mohr Siebeck, Heidelberg.

Tóth, M. (1995): Piacgazdaság és büntetôjog [Market economy and criminal law]. Magyar Jog, Vol. 42, No. 11, pp. 641-646.

Voszka, É. (2018): Az állami tulajdon pillanatai. Gazdaságtörténeti és tudománytörténeti nézöpontok [Moments in state ownership. Considerations in economic policy and in the history of the discipline]. Akadémai Kiadó, Budapest.

Zéman, Z. and Lentner, Cs. (2018): The Changing Role of Going Concern Assumption Supporting Management Decisions After Financial Crisis. Polish Journal of Management Studies, Vol. 18, No. 1, pp. 428441, https://doi.org/10.17512/pjms.2018.18.1.32. 